\title{
PENGEMBANGAN VIDEO PEMBELAJARANDENGAN APLIKASI CAMTASIA JURUSAN TATA KECANTIKAN RAMBUT
}

\author{
Mey Alsih Sihombing ${ }^{1}$, Sahat Siagian ${ }^{2}$, Abdul Hamid, K. $^{3}$ \\ ${ }^{1}$ Sekolah Menengah Kejuruan Negeri 3 Pematang Siantar, Sumatera Utara \\ ${ }^{2,3}$ Pascasarjana Universitas Negeri Medan \\ sihombingmeyalsih@gmail.com ${ }^{1}$
}

\begin{abstract}
Abstrak: Tujuan Penelitian ini adalah untuk mengetahui apakah video pembelajaran dengan aplikasi camtasia pada mata pelajaran pemangkasan dan penataan rambut layak digunakan pada siswa kelas kelas XI Kecantikan Rambut di Sekolah SMK Negeri 3 Pematangsiantar. Jenis penelitian ini adalah penelitian pengembangan. Model pengembangan produk pembelajaran ini merupakan model yang disusun secara terprogram dengan urutan yang sistematis dan memenuhi karakteristik siswa dalam belajar. Hasil penelitian menunjukkan bahwa (1) Secara keseluruhan media pembelajaran interaktif yang dikembangkan layak untuk digunakan sebagai media pembelajaran pada mata pelajaran Penataan dan Pemangkasan Rambut dengan presentase rata-rata sebesar 95,09\%, dengan nilai 5 skala likert dan berada pada criteria "Baik Sekali", (2) uji ahli materi mata pelajaran penataan dan pemangkasan rambut berada pada criteria baik sekali (97,11\%) (3) uji ahli desain pembelajaran berada pada criteria baik sekali (90,00\%) (4) uji ahli media berada pada criteria baik sekali (97,11\%), (5) uji perorangan berada pada criteria baik sekali $(96,58 \%),(6)$ uji kelompok kecil berada pada criteria baik sekali (95,80\%), (7) uji coba lapangan berada pada criteria baik sekali (93,95\%). Hasil pengembangan media interaktif menunjukan validasi ahli menunujukkan bahwa keseluruhan rata-rata dikategorikan "Baik Sekali" dan uji kelayakan menunujukkan bahwa keseluruhan rata-rata dikategorikan "Baik Sekali”.
\end{abstract}

Kata Kunci: Video Pembelajaran, Camtasia, Tata Kecantikan Rambut

\begin{abstract}
The purpose of this study was to determine whether the learning video with the application of camtasia in the subjects of hair trimming and styling is suitable for use in the eleventh grade students of Hair Beauty at SMK Negeri 3 Pematangsiantar. This type of research is development research. This learning product development model is a model that is arranged in a programmed order in a systematic order and meets the characteristics of students in learning. The results showed that (1) Overall the interactive learning media developed was feasible to be used as a learning medium in Hair Styling and Trimming subjects with an average percentage of $95.09 \%$, with a value of 5 Likert scale and were in the criteria of "Very Good ", (2) expert test material for hair styling and trimming subjects is in very good criteria (97.11\%) (3) learning design expert test is in excellent criteria (90.00\%) (4) media expert test is in very good criteria (97.11\%), (5) individual tests are in very good criteria (96.58\%), (6) small group tests are in very good criteria (95.80\%), (7) tests Try the field is in very good criteria (93.95\%). The results of the development of interactive media show that expert validation shows that the overall average is categorized as "Very Good" and the fit test shows that the overall average is categorized as "Very Good".
\end{abstract}

Keywords: Learning Videos, Camtasia, Hair Beauty

\section{PENDAHULUAN}

Dalam proses pembelajaran merupakan salah satu proses perubahan yang terjadi di dalam diri manusia yang melibatkan seluruh aspek baik secara fisik maupun psikis. Sebagai perancang pengajaran, seorang guru berperan dalam mengelola seluruh proses pembelajaran dengan menciptakan kondisi belajar sedemikian rupa sehingga setiap anak dapat belajar secara efektif dan efesien ( Surya 2008:116 ).

Materi pangkas rambut merupakan materi yang berkelanjutan dari satu kesatuan dan kompleks. Suatu teknik pangkas rambut, jika hanya diperoleh dengan membaca teori-teori dari buku cetak, tidak tersampaikan dengan jelas bagaimana maksud dan tujuannya. Teoriteori yang ada dalam buku atau modul tidak dapat menjadi sarana pembentukkan kreatifitas dan kemandirian siswa, karena siswa tidak melihat langsung teknik aplikasi pangkas tersebut. Salah satu materi pengajaran di SMK Negeri 3 Pematangsiantar bidang tata kecantikan rambut adalah pemangkasan rambut dasar. Pembelajaran Tata Kecantikan terdiri dari dua kelompok besar, yaitu kelompok Instruksional dan Non-Instruksional. Pembelajaran Instruksional adalah pembelajaran yang dirancang secara terstruktur 
dalam kurikulum yang dikelompokkan dalam program normatif, adaptif, dan produktif. Kompetensi keahlian Tata Kecantikan Rambut, memiliki salah satu program produktif yang standart kompetensinya harus dicapai oleh setiap siswa yaitu melakukan pemangkasan rambut dasar dan didalamnya terdapat beberapa kompetensi dasar diantaranya adalah melakukan pemangkasan rambut dasar yang terdiri dari pemangkasan rambut solid, pangkasan oval, pangkasan segi, pangkasan diagonal kedepan,dan pangkasan graduasi. Melalui sub kompetensi dasar tersebut, siswa diharapkan mampu dan terampil dalam melakukan pemangkasan rambut dasar. Umumnya dalam meningkatkan kualitas lulusan SMK khususnya SMK, khususnya jurusan tata kecantikan rambut, banyak faktor yang mempengaruhinya, salah satunya adalah sarana dan prasarana seperti gedung sekolah, laboratorium praktek, perpustakaan, serta fasilitas alat praktek.

Berdasarkan hasil observasi yang telah dilakukan peneliti melihat bahwa guru mengajar dominan menggunakan model konvensional dengan metode ceramah dan penugasan, serta menggunakan papan tulis biasa sebagai media, walaupun pihak sekolah telah menyediakan fasilitas mengajar seperti Infocus-LCD, namun guru belum memanfaatkannya secara optimal. Selain itu, permasalahan yang sering terjadi dari hasil wawacara kepada guru bidang studi bahwa penggunaan media yang masih rendah, karena guru hanya menyampaikan materi secara verbal tanpa ada hubungan interaktif dari siswa, selanjutnya media yang digunakan juga kurang efektif, dimana media tersebut masih menggunakan media cetak seperti buku, majalah, modul dan sebagainya, sehingga membuat siswa menjadi jenuh untuk belajar. Sedangkan penggunaan media audio dan visual seperti video atau film, dan media lainnya (computer) masih belum di terapkan dengan baik. Sangat disayangkan jika sekolah menuju Standart Internasional (SBI) seperti SMK Negeri 3 Pematangsiantar ini, masih belum mampu menerapkan media pembelajaran yang lebih baik. Melihat kondisi itu, maka perlu diperbaiki media pembelajaran agar lebih informatif dan inovatif untuk memberdayakan siswa.

Meningkatkan kualitas dan motivasi belajar siswa, seperti menurut Arikunto $(2005 ; 121)$ bahwa guru diharapkan sanggup menciptakan proses pembelajaran yang berkualitas tinggi sehingga mampu menghasilkan prestasi belajar siswa. Fungsi yang dapat diperankan guru dalam pembelajaran, yakni : (1) sebagai perancang pembelajaran, dimana seorang guru diharapkan mampu merancang pembelajaran agar dapat terlaksana secara efektif dan efisien, (2) pengelola pembelajaran, dimana seorang guru harus mampu mengelola seluruh proses kegiatan pembelajaran dengan menciptakan kondisi belajar yang dinamis dan kondusif, dan (3) evaluator pembelajaran. Berkaitan dengan fungsi tersebut guru dituntut memiliki pengetahuan tentang prinsip-prinsip belajar sebagai dasar untuk merancang kegiatan pembelajaran dengan memilih media pembelajaran, merumuskan tujuan, memilih bahan, memilih metode/pendekatan dan guru juga dituntut secara terus menerus memantau hasil belajar yang telah dicapai siswa, mengevaluasi kegiatan pembelajaran dan selalu berusaha meningkatkannya.

Tahapan dalam belajar tergantung pada fase-fase belajar, dan salah satu tahapannya adalah yang dikemukakan oleh witting yaitu; a) Tahap acquisition, yaitu tahapan perolehan informasi; b) Tahap storage, yaitu tahapan penyimpanan informasi; c) Tahap retrieval, yaitu tahapan pendekatan kembali informasi (Syah, 2003:225)

Di dalam Kamus Lengkap Bahasa Indonesia kata pangkas diartikan sebagai kata memenggal, memotong, memendekkan. Secara "etimology" pemangkasan adalah tindakan memotong yang sudah dilakukan sejak zaman dahulu, dengan cara yang sederhana, dengan berkembangnya zaman dan tuntutan masyarakat pada saat itu, yang menginginkan perubahan model,maka para ahli pemangkas rambut menciptakan beberapa model pemangkasan dengan bentuk yang indah. Rosmatailis, dkk. (2008:80) secara Ethymologi pangkas adalah tindakan memotong yang sudah dilakukan sejak zaman dahulu, dengan cara sederhana dengan perkembangan zaman dan tuntutan masyarakat pada saat itu. Pada abad XX para ahli pangkas rambut menciptakan beberapa model pangkas yang menghasilkan bentuk yang sangat indah.

Sedangkan menurut Kusumawardani (2003) bentuk dasar pangkas rambut adalah dasardasar pemangkasan berbagai model pemangkasan rambut yang dapat digunakan sebagai patokan berbagai model pangkas rambut. Bentuk dasar pangkas rambut, terdiri 
dari pemangkasan rambut:a.Solid, b.Graduasi, c.Layer.

Dengan adanya teknik-teknik pemangkasan, maka dapat disimpulkan pemangkasan adalah tindakan untuk mengurangi panjang rambut semula dengan teknik tertentu, sesuai dengan bentuk wajah, jenis rambut, perawatan, pekerjaan, dan kepribadian seseorang, sehingga menghasilkan model pangkasan yang diinginkan sesuai dengan trend yang berkembang. Menurut (Rosmatailis : 2008) Adapun tujuan dari pemangkasan ini adalah mengurangi panjang rambut, merapikan rambut, merubah penampilan, serta mengikuti mode yang sedang berkembang (trend).

\section{Hakikat Pengembangan Media Video Pembelajaran Pemangkasan Rambut.}

Segala sesuatu yang dapat digunakan untuk menyalurkan pesan yang dapat merangsang pikiran, perasaan, perhatian, dan kemauan siswa untuk belajar (Miarso, 1989: 221). Perkembangan ilmu pengetahuan dan teknologi semakin mendorong upaya-upaya pembaharuan dalam pemanfaatan teknologi dalam pembelajaran. Para guru dituntut supaya bisa menggunakan alat-alat yang telah disediakan sekolah sebagai penunjang keberhasilan proses belajar. Di samping itu guru juga dituntut supaya bisa mengembangkaan keterampilan membuat media pembelajaran yang akan digunakannya apabila media tersebut belum tersedia.

Menurut AECT (Assosiation for Educational Communication and Technology, 1977). Media merupakan segala bentuk dan saluran yang digunakan dalam proses penyampaian informasi. Gerlach dan Ely berpendapat bahwa media apabila dipahami secara garis besar adalah manusia, materi, atau kejadian yang membangun kondisi yang membuat siswa mampu memperoleh pengetahuan, keterampilan, atau sikap. Briggs berpendapat bahwa media merupakan alat untuk memberikan perangsang bagi siswa supaya terjadi proses belajar. Sedangkan Gagne berpendapat bahwa berbagai jenis komponen dalam lingkungan siswa yang dapat merangsang siswa untuk belajar.

Berdasarkan defenisi tersebut, dapat dikatakan bahwa media pembelajaran merupakan sarana perantara dalam proses pembelajaran, segala sesuatu yang dapat digunakan untuk menyalurkan pesan sehingga dapat merangsang perhatian, minat, pikiran, dan perasaan siswa dalam kegiatan belajar untuk mencapai tujuan belajar. Media harus bermanfaat sebagai berikut: (1) memperjelas pesan agar tidak verbalistis, (2) mengatasi keterbatasan ruang, waktu, tenaga, dan daya indra, (3) menimbulkan gairah belajar, berinteraksi secara langsung antara peserta didik dan sumber belajar, (4) memungkinkan anak belajar mandiri sesuai dengan bakat dan kemampuan visual, (5) memberi rangsangan, (6) proses pembelajaran mengandung lima komponen komunikasi, yaitu guru (komunikator), dan tujuan pembelajaran. Jadi, media pembelajaran adalah segala sesuatu yang dapat digunakan untuk menyalurkan pesan/bahan pembelajaran sehingga dapat merangsang perhatian, minat, pikiran, dan perasaan peserta didik dalam kegiatan belajar untuk mencapai tujuan pembelajaran.

Selain itu, kontribusi media pembelajaran menurut Kemp and Dayton (1985:78) adalah sebagai berikut: (a) penyampaian pesan pembelajaran dapat lebih terstandart, (b) pembelajaran dapat lebih menarik, (c) pembelajaran menajdi lebih interaktif dengan menerapkan teori belajar, (d) waktu pelaksanaan pembelajaran dapat diperpendek, (e) kualitas pembelajaran dapat ditingkatkan, (f) proses pembelajaran dapat berlangsung kapanpun dan dimanapun diperlukan, (g) sikp positif siswa terhadap materi pembelajaran serta proses pembelajaran serta proses pembelajaran dapat ditingkatkan, (h) peran guru mengalami perubahan ke arah yang positif.

Pengembangan dalam bahasa inggris disebut development, yang mempunyai makna : pertama, pengelolaan frase-frase dan motifmotif dengan detail terhadap tema atau yang dikemukakan sebelumnya, kedua: suatu bagian dari karangan yang memperluas, memperdalam dan menguatkan argumentasi yang terdapat dalam eksposisi, komaruddin dkk (2000;186). Penelitian pengembangan adalah kegiatan yang menghasilkan rancangan atau produk yang dapat dipakai untuk memecahkan masalah aktual, Rusjoni dkk (2008;39). Dalam hal ini, kegiatan pengembangan ditekankan pada pemanfaatan teori, konsep, prinsip atau temuan penelitian untuk memecahkan masalah. Pengembangan (development) merupakan proses penterjemahan spesifikasi rancangan menjadi bentuk fisik, Seels \& Richey (1994;35) mendesripsikan pengembangan sebagai; (a) pesan yang terkandung di dalam isi, (b) stategi 
pembelajaran yang mengandung teori, (c) perwujutan dari teknologi yang berupa perangkat keras dan lunak serta bahan-bahan media pembelajaran. Terkait dengan pengembangan ini, Miarso $(2004 ; 419)$ mengemukakan bahwa bila dikaji secara empiris, pengembangan adalah cara yang dilakukan dengan menciptakan sesuatu model terbatas yang diawasi secara cermat terlebih berbagai komponen pengembangan dicobakan, dinilai dan disempurnakan.

Model pengembangan pembelajaran berfungsi mengarahkan kita dalam mendesain pembelajaran yang dapat kita gunakan sebagai pedoman dalam pembelajaran guna mencapai pembelajaran efektif, efesien, berdaya guna, menarik dan humanis. Senada dengan hal tersebut model pembelajaran Dick \&Carey (2005:5) adalah salah satu contoh model pengembangan yang berorientasi pada hasil, karena penerapan konsep-konsep dan prinsipprinsip perancangannyaakan menghasilkan bahan belajar mandiri.

Berdasarkan latar belakang dan batasan masalah di atas, maka masalah penelitian dirumuskan yaitu apakah pengembangan video pembelajaran dengan aplikasi camtasia pada mata pelajaran pemangkasan dan penataan rambut layak digunakan?

\section{METODE}

Penelitian ini akan dilakukan di SMK Negeri 3 yang beralamat di Jalan. Raya Medan Km 10,5 Sinaksak Pematang Siantar. Metode penelitian yang digunakan adalah research and development, karena penelitian ini termasuk penelitian pengembangan pendidikan yang dimaksudkan untuk menghasilkan produk pembelajaran yang layak dimanfaatkan dan sesuai kebutuhan. Borg dan Gall (1983) memberikan batasan tentang penelitian pengembangan sebagai usaha untuk mengembangkan dan memvalidasi produkproduk yang digunakan dalam pendidikan. Pengertian yang hampir sama dikemukakan oleh Asim (Waldopo, 2002: 1) bahwa penelitian pengembangan dalam pembelajaran adalah proses yang digunakan untuk mengembangkan dan memvalidasi produk-produk yang digunakan dalam proses pembelajaran.

Borg \& Gall (1983:772) mengemukakan penelitian pengembangan adalah penelitian yang berorientasi untuk mengembangkan dan memvalidasi produk-produk yang digunakan dalam pendidikan. Menurut Sugiyono (2009:297) penelitian dan pengembangan adalah metode penelitian yang digunakan untuk menghasilkan produk tertentu dan menguji keefektifan produk tersebut. Senada dengan pendapat Syaodih (2010:164) penelitian pengembangan adalah suatu proses atau langkah-langkah untuk mengembangkan suatu produk baru atau menyempurnakan produk yang telah ada. Produk tersebut dapat berupa benda atau perangkat keras (hardware) seperti buku, modul, alat bantu pembelajaran atau perangkat lunak (software) seperti program computer, pembelajaran di kelas, model-model pendidikan.

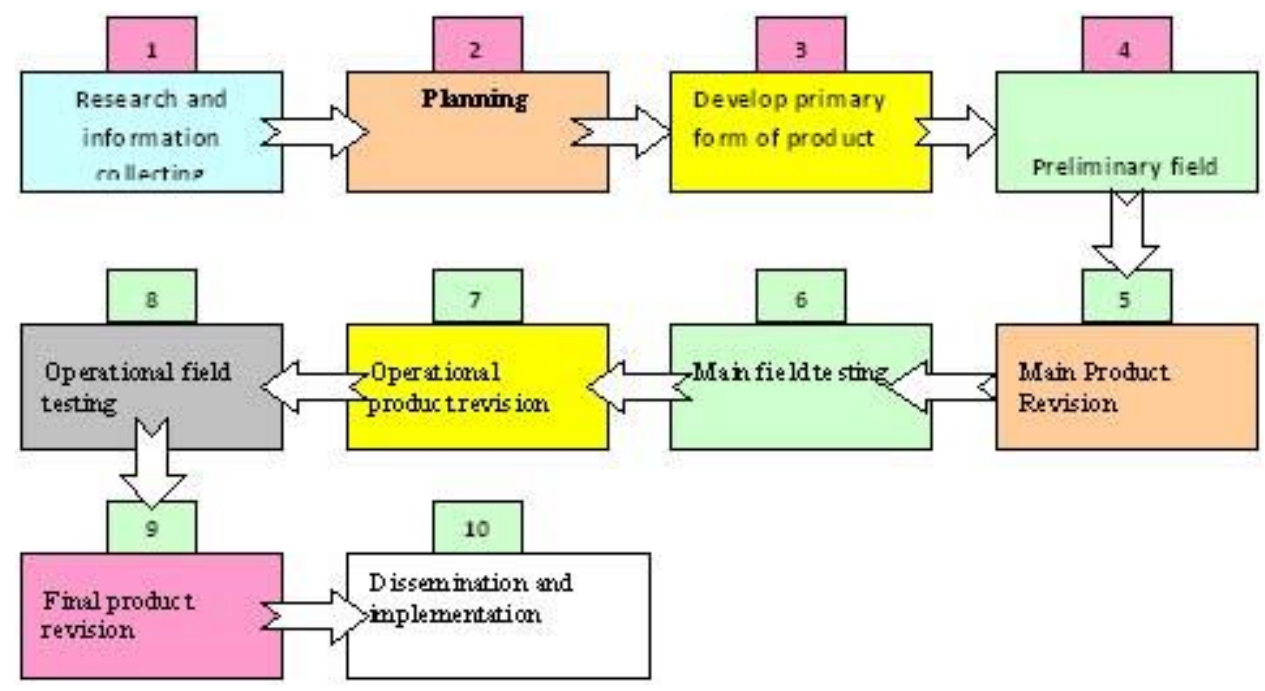

Gambar 1. Skema Prosedur Pengembangan Hasil Adaptasi dari Prosedur Pengembangan Borg \& Gall (Sumber: Borg \& Gall, 1983:775) 
Keterangan:

1. Research and information collecting; termasuk dalam langkah ini antara lain studi literatur yang berkaitan dengan permasalahan yang dikaji, dan persiapan untuk merumuskan kerangka kerja penelitian;

2. Planning; termasuk dalam langkah ini merumuskan kecakapan dan keahlian yang berkaitan dengan permasalahan, menentukan tujuan yang akan dicapai pada setiap tahapan, dan jika mungkin/diperlukan melaksanakan studi kelayakan secara terbatas;

3. Develop preliminary form of product, yaitu mengembangkan bentuk permulaan dari produk yang akan dihasilkan. Termasuk dalam langkah ini adalah persiapan komponen pendukung, menyiapkan pedoman dan buku petunjuk, dan melakukan evaluasi terhadap kelayakan alat-alat pendukung;

4. Preliminary field testing, yaitu melakukan ujicoba lapangan awal dalam skala terbatas. dengan melibatkan subjek sebanyak 6 - 12 subjek. Pada langkah ini pengumpulan dan analisis data dapat dilakukan dengan cara wawancara, observasi atau angket;

5. Main product revision, yaitu melakukan perbaikan terhadap produk awal yang dihasilkan berdasarkan hasil ujicoba awal. Perbaikan ini sangat mungkin dilakukan lebih dari satu kali, sesuai dengan hasil yang ditunjukkan dalam ujicoba terbatas, sehingga diperoleh draft produk (model) utama yang siap diujicoba lebih luas;

6. Main field testing, uji coba utama yang melibatkan seluruh siswa.

7. Operational product revision, yaitu melakukan perbaikan/penyempurnaan terhadap hasil uji coba lebih luas, sehingga produk yang dikembangkan sudah merupakan desain model operasional yang siap divalidasi;

8. Operational field testing, yaitu langkah uji validasi terhadap model operasional yang telah dihasilkan;

9. Final product revision, yaitu melakukan perbaikan akhir terhadap model yang dikembangkan guna menghasilkan produk akhir (final);

10. Dissemination and implementation, yaitu langkah menyebarluaskan produk/model yang dikembangkan

\section{Tahap Uji Coba Produk}

Uji coba dimaksudkan untuk mengumpulkan data dalam rangka evaluasi formatif yang dijadikan dasar dalam menetapkan pakah produk tersebut telah benarbenar layak digunakan dan menarik. Kegiatan yang dilakukan antara lain:

Adapun tahapan dari desain uji coba sebagai berikut: (a) validasi ahli materi, (b) validasi media video pembelajaran, (c) analisis konseptual, (d) revisi produk tahap I, berdasarkan penilaian yang berupa masukan, kritik atau saran dari 2 ahli materi dan 3 ahli media, 2 ahli desain instruksional untuk dilakukan perbaikan, (e) uji coba terhadap siswa (satu-satu/perorangan/kelompok kecil). Penilaian ini berdasarkan angket yang telah diisi oleh 3 siswa (uji perorangan) dan 9 siswa orang (uji coba kelompok kecil), (f) analisis konseptual dan produk, (g) revisi produk tahap II, (h) uji coba lapangan terhadap siswa, (i) penilaian mengenai daya tarik dan kelayakan produk, (j) analisis empiric tahap III, (k) revisi kecil, (l) penilaian mengenai daya tarik dan kelayakan produk, (m) revisi kecil.

Produk pengembangan video pembelajaran terdiri dari 2 orang ahli desain pembelajaran, 2 orang ahli materi pembelajaran, 2 orang ahli media, dan pemakai produk yaitu peserta didik SMK Negeri 3 Pematangsiantar yang terdiri dari 3 orang siswa kelas XI jurusan tata kecantikan rambut SMK Negeri 3 Pematangsiantar untuk uji coba perorangan, 9 orang untuk uji coba kelompok kecil.

Uji coba produk dalam pengembangan ini dilaksanakan dengan melalui beberapa langkah sebagai berikut:

a) Langkah pertama, menentukan sasaran uji coba yaitu ahli pembelajaran, ahli materi, ahli video, siswa. Masukkan yang diharapkan dari masing-masing ahli adalah kesesuaian uraian materi dengan standart kompetensi dan kompetensi dasar, keakuratan materi, dan materi pendukung pembelajaran. Kemudian menganalisis konseptual serta revisi pengembangan produk tahap I

b) Langkah kedua menetapkan subjek uji coba yang didasarkan pada criteria pendidikan, keahlian, juga ketersediaan waktu dan tenaga untuk memberikan data yang diperlukan.

c) Langkah ketiga pelaksanaan tinjauan ahli sebelum uji coba perorangan dan lapangan, terlebih dahulu produk diberikan kepada 
ahli untuk mendapatkan saran dan masukkan sesuai dengan keahliannya masing-masing.

d) Langkah keempat uji coba perorangan.

e) Langkah kelima uji coba kelompok kecil. Hal ini dilakukan guna mengetahui apakah masih terdapat kekurangan-kekurangan yang perlu diperbaiki dari produk yang dikembangkan setelah diskusi baik berdasarkan tinjauan ahli maupun pada uji coba perorangan. Jika terdapat kekurangan maka dilakukan perbaikan revisi III. Jika tidak, maka produk dapat dinyatakan layak sebagai sumber belajar di lapangan.

Analisis data dalam penelitian ini menggunkana analisis deskriptif kuantitatif. Semua data yang terkumpul dianalisis dengan teknik statistic deskriptif yang secara kuantitatif dipisahkan menurut kategori untuk mempertajam penilaian dalam menarik kesimpulan. Data kualitatif yang berupa pernyataan sangat kurang layak, kurang layak, sedang, layak dan sangat layak diubah menjadi data kuantitatif dengan skala 1 sampai 5 . Hasilnya dirata-rata dan digunakan untuk menilai kualitas software pembelajaran. Criteria software akan dikonversikan menjadi nilai dengan skala lima menggunakan skala Likert yang dianalisis secara deskriptif persentase dengan rumus sebagai berikut (Sugiyono,2011:318):

$$
\mathrm{X}=\frac{\text { jumlahskoryangdiperoleh }}{\text { jumlahskoridealselurwhitem }} \times 100 \%
$$

Dengan kriteria penilaian seperti yang tertulis pada tabel 1 berikut ini.

Tabel 1. Kriteria Penilaian

\begin{tabular}{|c|c|c|}
\hline Nilai & Kriteria & Persentase \\
\hline 5 & Sangat Baik & $81 \% \leq \mathrm{X} \leq 100 \%$ \\
\hline 4 & Baik & $61 \% \leq \mathrm{X} \leq 80 \%$ \\
\hline 3 & Sedang & $41 \% \leq \mathrm{X} \leq 60 \%$ \\
\hline 2 & Kurang Baik & $21 \% \leq \mathrm{X} \leq 40 \%$ \\
\hline 1 & Sangat Kurang & $0 \% \leq \mathrm{X} \leq 20 \%$ \\
\hline
\end{tabular}

\section{HASIL DAN PEMBAHASAN}

\section{Hasil}

\section{Hasil Uji Coba Tahap II/Uji Coba Perorangan}

Uji coba perorangan dilakukan pada 3 orang siswa kelas XI SMK Negeri 3 Pematangsiantar yang trdiri dari 1 orang siswa yang memiliki prestasi tinggi, 1 orang dengan prestasi sedang dan 1 orang lagi dengan prestasi rendah. Uji coba ini dilakukan di SMK N 3 Pematang siantar. Uji coba perorangan bertujuan untuk mengidentifikasi kekurangan produk pembelajaran setelah ditinjau ulang oleh tenaga ahli. Penilaian dan masukan ditujukan terhadap aspek kualitas materi pembelajaran dan aspek teknis/tampilan yang terdapat dalam Video Pembelajaran dengan Aplikasi Camtasia mata pelajaran Penataan dan Pemangkasan Rambut.

Tabel 2. Skor Penilaian Video Pembelajaran dengan Aplikasi Camtasia Mata Pelajaran Penataan dan Pemangkasan Rambut Pada Uji Coba Perorangan Di SMK Negeri 3 Pematangsiantar Tentang Kualitas Materi Pembelajaran

\begin{tabular}{|c|c|c|c|c|c|c|c|}
\hline \multirow{2}{*}{$\begin{array}{l}\mathbf{N} \\
\mathbf{o}\end{array}$} & \multirow[t]{2}{*}{ Indikator Penilaian } & \multicolumn{3}{|c|}{ Responden } & \multirow{2}{*}{$\begin{array}{l}\text { Jlh } \\
\text { Skor }\end{array}$} & \multirow{2}{*}{$\begin{array}{l}\text { Rata- } \\
\text { rata }\end{array}$} & \multirow[t]{2}{*}{ Kriteria } \\
\hline & & 1 & 2 & 3 & & & \\
\hline 1 & Kesesuai materi & 4 & 5 & 5 & 14 & $93,3 \%$ & Sangat Baik \\
\hline 2 & Kejelasan Petunjuk belajar & 5 & 5 & 5 & 15 & $100 \%$ & Sangat Baik \\
\hline 3 & $\begin{array}{l}\text { Kemudahan memahami kalimat } \\
\text { pada teks }\end{array}$ & 5 & 5 & 5 & 15 & $100 \%$ & Sangat Baik \\
\hline 4 & $\begin{array}{l}\text { Kemudahan memahami } \\
\text { pembelajaran }\end{array}$ & 5 & 5 & 5 & 15 & $100 \%$ & Sangat Baik \\
\hline 5 & Ketepatan urutan penyajian & 4 & 5 & 5 & 14 & $93,3 \%$ & Sangat Baik \\
\hline 6 & Kecakupan latihan & 5 & 4 & 5 & 14 & $93,3 \%$ & Sangat Baik \\
\hline 7 & Kejelasan umpan balik & 3 & 3 & 5 & 11 & $73,3 \%$ & Baik \\
\hline 8 & Bantuan belajar dengan program & 5 & 5 & 5 & 15 & $100 \%$ & Sangat Baik \\
\hline & Rata-rata & 90 & 92,5 & 100 & 94,17 & $94,17 \%$ & Sangat Baik \\
\hline
\end{tabular}


Tabel 2. menunjukkan tanggapan 3 orang siswa pada uji coba terhadap Video Pembelajaran dengan Aplikasi Camtasia mata pelajaran Penataan dan Pemangkasan Rambut dari aspek kualitas materi pembelajaran secara keseluruhan dinyatakan dalam kriteria "Sangat Baik".

Penilaian siswa kepada media pembelajaran interkatif terhadap aspek kualitas teknis/tampilan dapat dilihat pada tabel 3.

Tabel 3. Skor Penilaian Video Pembelajaran dengan Aplikasi Camtasia Mata Pelajaran Penataan dan Pemangkasan Rambut Pada Uji Coba Perorangan Tentang Aspek Kualitas Teknis/ Tampilan

\begin{tabular}{|c|l|c|c|c|c|c|c|}
\hline \multirow{2}{*}{ No } & \multirow{2}{*}{ Indikator Penilaian } & \multicolumn{3}{|c|}{ Responden } & \multirow{2}{*}{ Jumlah } & \multirow{2}{*}{$\begin{array}{c}\text { Rata- } \\
\text { rata }\end{array}$} & \multirow{2}{*}{ Kriteria } \\
\cline { 3 - 5 } & & $\mathbf{1}$ & $\mathbf{2}$ & $\mathbf{3}$ & & & \\
\hline 1 & Keindahan Tampilan Layar & 5 & 5 & 5 & 15 & $100 \%$ & Sangat Baik \\
\hline 2 & Keterbacaan Teks & 5 & 5 & 5 & 15 & $100 \%$ & Sangat Baik \\
\hline 3 & Kualitas Gambar dan Animasi & 5 & 5 & 5 & 15 & $100 \%$ & Sangat Baik \\
\hline 4 & Komposisi Warna & 5 & 5 & 5 & 15 & $100 \%$ & Sangat Baik \\
\hline 5 & Navigasi & 5 & 4 & 5 & 14 & $93,3 \%$ & Sangat Baik \\
\hline 6 & Daya Dukung Musik & 5 & 5 & 5 & 15 & $100 \%$ & Sangat Baik \\
\hline 7 & Interaksi & 5 & 5 & 5 & 15 & $100 \%$ & Sangat Baik \\
\hline \multicolumn{2}{c}{ Rata-rata } & 100 & 97 & 100 & 99 & $99 \%$ & Sangat Baik \\
\hline
\end{tabular}

Tanggapan siswa pada uji coba perorangan diperlihatkan pada tabel 3 menjelaskan bahwa Video Pembelajaran dengan Aplikasi Camtasia dari aspek kualitas teknis/tampilan secara keseluruhan dinilai "Sangat Baik".
Hasil penilaian pada uji coba perorangan terhadap aspek kualitas materi pembelajaran terhadap Video Pembelajaran dengan Aplikasi Camtasia mata pelajaran Penataan dan Pemangkasan Rambut dirangkum pada tabel 4 .

Tabel 4. Tingkat Kecenderungan Penilaian Terhadap Aspek Kualitas Materi Pembelajaran Video Pembelajaran dengan Aplikasi Camtasia Mata Pelajaran Penataan dan Pemangkasan Rambut Pada Uji Coba Perorangan.

\begin{tabular}{|l|l|c|c|c|}
\hline No & \multicolumn{1}{|c|}{ Kategorisasi } & Rentang Skor & Frekuensi & Persentase \\
\hline 1 & Sangat Baik & $81 \%<\mathrm{X}<100 \%$ & 3 & 100 \\
\hline 2 & Baik & $61 \%<\mathrm{X}<80 \%$ & 0 & 0 \\
\hline 3 & Sedang & $41 \%<\mathrm{X}<60 \%$ & 0 & 0 \\
\hline 4 & Kurang Baik & $21 \%<\mathrm{X}<40 \%$ & 0 & 0 \\
\hline 5 & Sangat Kurang & $0 \%<\mathrm{X}<20 \%$ & 0 & 0 \\
\hline \multicolumn{2}{|c|}{ Jumlah } & $\mathbf{3}$ & $\mathbf{1 0 0 \%}$ \\
\hline
\end{tabular}

Tabel 4. menunjukkan hasil tanggapan siswa terhadap aspek kualitas materi pembelajaran dan kualitas teknis/tampilan $\quad(100 \%)$ menunjukkan penilaiandengan kriteria "Sangat Baik".

\section{2) Analisis Data Hasil Uji Coba Tahap II Uji Coba Perorangan}

Tabel 5 berikut menunjukkan presentase rata-rata hasil penilaian yang dilakukan pada uji coba perorangan. Penilaian yang dilakukan terhadap aspek kualitas materi pembelajaran yakni sebesar 94,17\% dan aspek kualitas teknis/tampilan sebesar 99,00\% dan masing-masing termasuk kategori Sangat Baik. Berdasarkan hasil penilaian pada Video Pembelajaran dengan Aplikasi Camtasia mata pelajaran Penataan dan Pemangkasan Rambut pada uji coba perorangan tidak terdapat saran perbaikan. 
Tabel 5. Persentase Rata-Rata Hasil Penilaian Terhadap Video Pembelajaran dengan Aplikasi Camtasia Mata Pelajaran Penataan dan Pemangkasan Rambut Pada Uji Coba Perorangan

\begin{tabular}{|l|l|c|c|}
\hline No & Kategorisasi & Persentase Rata-rata & Kriteria \\
\hline $\mathbf{1}$ & Aspek kualitas materi pembelajaran & $94,17 \%$ & Sangat Baik \\
\hline $\mathbf{2}$ & Aspek kualitas teknis/tampilan & $99,0 \%$ & Sangat Baik \\
\hline \multicolumn{2}{|c|}{ Rata-rata } & $96,58 \%$ & Sangat Baik \\
\hline
\end{tabular}

Persentase rata-rata hasil penilaian Video Pembelajaran dengan Aplikasi Camtasia pada uji coba perorangan yang dilakukan pada 3 orang itu dengan kemampuan, 1 orang siswa

\section{Hasil Uji Coba Tahap III/Uji Coba Kelompok Kecil \\ 1) Deskripsi Data Hasil Uji Coba Kelompok Kecil \\ Uji coba kelompok kecil produk} Video Pembelajaran dengan Aplikasi Camtasia ini dilakukan terhadap 9 orang siswa, yang terdiri dari 3 orang siswa yang berprestasi tinggi, 3 orang siswa yang berprestasi sedang dan 3 orang siswa yang berprestasi rendah. Data uji coba kelompok dengan prestasi belajar tinggi, 1 orang siswa dengan prestasi belajar sedang dan 1 orang siswa dengan prestasi belajar rendah.

kecil ini dipergunakan untuk mengetahui beberapa kelemahan,kekurangan dan hambatan yang dihadapi ketika prouduk Video Pembelajaran dengan Aplikasi Camtasia dipergunakan. Uji coba kelompok kecil ini dimaksud untuk mengambil pengalaman awal bagi peneliti sebelum produk diuji cobakan ke lapangan. Hasil evaluasi pada aspek kualitas materi pembelajaran dapat dilihat pada tabel 6 .

Tabel 6. Skor Penilaian Video Pembelajaran dengan Aplikasi Camtasia Mata Pelajaran Penataan dan Pemangkasan Rambut Uji Coba Kelompok Kecil Pada Aspek Kualitas Materi Pembelajaran

\begin{tabular}{|c|l|c|c|c|c|c|c|c|c|}
\hline \multirow{2}{*}{ No } & \multirow{6}{*}{ Indikator Penilaian } & \multicolumn{5}{|c|}{ Skor } & \multirow{2}{*}{ Jumlah } & $\begin{array}{c}\text { Rata- } \\
\text { Rata }\end{array}$ & Kriteria \\
\cline { 5 - 9 } & & $\mathbf{1}$ & $\mathbf{2}$ & $\mathbf{3}$ & $\mathbf{4}$ & $\mathbf{5}$ & & & \\
\hline $\mathbf{1}$ & Kesesuaian materi & & & & 2 & 7 & 43 & $96 \%$ & Sangat Baik \\
\hline $\mathbf{2}$ & Kejelasan petunjuk belajar & & & & 1 & 8 & 44 & $97 \%$ & Sangat Baik \\
\hline $\mathbf{3}$ & $\begin{array}{l}\text { Kemudahanmemahami } \\
\text { kalimat pada teks }\end{array}$ & & & 1 & 8 & 44 & $97 \%$ & Sangat Baik \\
\hline $\mathbf{4}$ & $\begin{array}{l}\text { Kemudahan memahami } \\
\text { pembelajaran }\end{array}$ & & & 1 & 8 & 44 & $97 \%$ & Sangat Baik \\
\hline $\mathbf{5}$ & Ketepatan urutan penyajian & & & & 3 & 6 & 42 & $93 \%$ & Sangat Baik \\
\hline $\mathbf{6}$ & Kecukupan latihan & & & & 3 & 6 & 42 & $93 \%$ & Sangat Baik \\
\hline $\mathbf{7}$ & Kejelasan umpan balik & & & 3 & 2 & 4 & 37 & $83 \%$ & Sangat Baik \\
\hline $\mathbf{8}$ & $\begin{array}{l}\text { Bantuan belajar dengan } \\
\text { program }\end{array}$ & & & 1 & 8 & 44 & $97 \%$ & Sangat Baik \\
\hline & Rata-rata & & & & & & 95,3 & $95,3 \%$ & Sangat Baik \\
\hline
\end{tabular}

Penilaian pada aspek kualitas materi pembelajaran untuk uji coba kelompok kecil yang tampak pada tabel 6 menunjukkan bahwa secara keseluruhan dalam kriteria "Sangat Baik".

Hasil evaluasi terhadap Video Pembelajaran dengan Aplikasi Camtasia mata pelajaran Penataan dan Pemangkasan Rambut pada aspek kualitas teknis/tampilan dapat dilihat pada tabel 4.30. penilaian pada aspek kualitas teknis/tampilam untuk uji coba kelompok kecil yang tampak pada tabel 7 menunjukkan bahwa mayoritas dalam kriteria "Sangat Baik" 
Tabel 7. Skor Penilaian Video Pembelajaran dengan Aplikasi Camtasia Mata Pelajaran Penataan dan Pemangkasan Rambut Uji Coba Kelompok Kecil Pada Aspek Kualitas Teknis/Tampilan

\begin{tabular}{|c|l|c|c|c|c|c|c|c|c|}
\hline \multirow{2}{*}{ No } & \multirow{2}{*}{ Indikator Penilaian } & \multicolumn{5}{|c|}{ Skor } & \multirow{2}{*}{ Jumlah } & \multirow{2}{*}{ Rata-rata } & \multirow{2}{*}{ kriteria } \\
\cline { 5 - 8 } & & $\mathbf{1}$ & $\mathbf{2}$ & $\mathbf{3}$ & $\mathbf{4}$ & $\mathbf{5}$ & & & \\
\hline 1 & Keindahan tampilan layar & & & & 1 & 8 & 44 & $97 \%$ & Sangat Baik \\
\hline 2 & Keterbacaan teks & & & & 1 & 8 & 44 & $97 \%$ & Sangat Baik \\
\hline 3 & Kualitas gambar dan animasi & & & & 1 & 8 & 44 & $97 \%$ & Sangat Baik \\
\hline 4 & Komposisi warna & & & & 1 & 8 & 44 & $97 \%$ & Sangat Baik \\
\hline 5 & Navigasi & & & & 4 & 5 & 41 & $92 \%$ & Sangat Baik \\
\hline 6 & Daya dukung musik & & & 1 & 8 & 44 & $97 \%$ & Sangat Baik \\
\hline 7 & Interaksi & & & & 1 & 8 & 44 & $97 \%$ & Sangat Baik \\
\hline \multicolumn{2}{|c|}{ Rata-rata } & & & & & & 96,28 & $96,28 \%$ & Sangat Baik \\
\hline
\end{tabular}

Hasil penilaian uji kelompok kecil terhadap aspek kualitas materi pembelajaran pada Video Pembelajaran dengan Aplikasi Camtasia mata pelajaran Penataan dan Pemangkasan Rambut dirangkum pada tabel
7. Berdasarkan tabel 4.31 hasil tanggapan peserta didik 8 orang $(88,89 \%)$ menyatakan "Sangat Baik" dan 1 orang $(11,11 \%)$ menyatakan "Baik".

Tabel 8. Tingkat Kecendrungan Penilaian Terhadap Aspek Kualitas Materi Pembelajaran Media Interaktif Mata Pelajaran Penataan dan Pemangkasan Rambut Pada Uji Coba Kelompok Kecil

\begin{tabular}{|c|l|c|c|c|}
\hline No & \multicolumn{1}{|c|}{ Kategorisasi } & Rentang skor & Frekuensi & Persentase \\
\hline 1 & Sangat Baik & $81 \%<\mathrm{X}<100 \%$ & 8 & 88,89 \\
\hline 2 & Baik & $61 \%<\mathrm{X}<80 \%$ & 1 & 11,11 \\
\hline 3 & Sedang & $41 \%<\mathrm{X}<60 \%$ & 0 & 0 \\
\hline 4 & Kurang Baik & $21 \%<\mathrm{X}<40 \%$ & 0 & 0 \\
\hline 5 & Sangat Kurang & $0 \%<\mathrm{X}<20 \%$ & 0 & 0 \\
\hline \multicolumn{2}{|r|}{ Jumlah } & $\mathbf{9}$ & $\mathbf{1 0 0} \%$ \\
\hline
\end{tabular}

Hasil penilaian uji coba kelompok kecil terhadap aspek kualitas teknis/tampilan pada Video Pembelajaran dengan Aplikasi Camtasia mata pelajaran Penataan dan Pemangkasan Rambut dirangkum pada tabel
4.32. Berdasarkan tabel 4.32 hasil tanggapan peserta didik 8 orang $(88,89 \%)$ menyatakan "Sangat Baik" dan 1 orang $(11,11 \%)$ menyatakan "Baik".

Tabel 9. Tingkat Kecendrungan Penilaian Terhadap Aspek Kualitas Teknis/Tampilan Video Pembelajaran dengan Aplikasi Camtasia Mata Pelajaran Penataan dan Pemangkasan Rambut Pada Uji Coba Kelompok Kecil

\begin{tabular}{|c|l|c|c|c|}
\hline No & \multicolumn{1}{|c|}{ Kategorisasi } & Rentang skor & Frekwensi & Persentase \\
\hline 1 & Sangat Baik & $81 \%<\mathrm{X}<100 \%$ & 8 & 88,89 \\
\hline 2 & Baik & $61 \%<\mathrm{X}<80 \%$ & 1 & 11,11 \\
\hline 3 & Sedang & $41 \%<\mathrm{X}<60 \%$ & 0 & 0 \\
\hline 4 & Kurang Baik & $21 \%<\mathrm{X}<40 \%$ & 0 & 0 \\
\hline 5 & Sangat Kurang & $0 \%<\mathrm{X}<20 \%$ & 0 & 0 \\
\hline \multicolumn{2}{|c|}{ Jumlah } & $\mathbf{9}$ & $\mathbf{1 0 0}$ \\
\hline
\end{tabular}

Pada uji coba kelompok kecil yang dilakukan pada 9 orang siswa, tidak terdapat permasalahan yang perlu direvisi/perbaikan terhadap produk media pembelajaran pada tahap III. 
2) Analisis Data Hasil Uji Coba Tahap III Kelompok Kecil

Tabel 10 berikut menunjukkan persentase rata-rata dari hasil penilaian terhadap Video Pembelajaran dengan Aplikasi Camtasia pada mata pelajaran
Penataan dan Pemangkasan Rambut pada uji coba kelompok kecil terhadap aspek kualitas materi pembelajaran adalah sebesar 95,3\% dan aspek kualitas teknis tampilan sebesar 96,28\% dan masing-masing termasuk kategori Sangat Baik

Tabel 10. Persentase Rata-Rata Hasil Penilaian Terhadap Video Pembelajaran dengan Aplikasi Camtasia Mata Pelajaran Penataan dan Pemangkasan Rambut Pada Uji Coba Kelompok Kecil

\begin{tabular}{|c|c|c|c|}
\hline No & Kategorisasi & Persentase rata-rata & Kriteria \\
\hline 1 & Aspek kualitas materi pembelajaran & $95,3 \%$ & Sangat Baik \\
\hline 2 & Aspek kualitas teknis/tampilan & $96,28 \%$ & Sangat Baik \\
\hline \multicolumn{2}{r|}{ Rata-rata } & $95,8 \%$ & Sangat Baik \\
\hline
\end{tabular}

\section{Hasil Uji Coba Tahap IV/Uji Coba} Lapangan

1) Deskripsi Data Hasil Uji Coba Tahap IV/Uji CobaLapangan

Uji coba lapangan yang dilakukan terhadap kelas XI-1 Tata Kecantikan Rambut yang berjumlah 26 orang. Hasil uji coba lapangan akan dijadikan data untuk mengukur kelayakan dari produk yang dikembangkan, sekaligus untuk mengetahui sampai sejauh mana manfaat produk tersebut bagi hasil belajar pemakaiannya.

Hasil evaluasi terhadap paket pembelajaran pada aspek kualitas materi pmbelajaran dapat dilihat pada tabel 11 ini menunjukkan hasil tanggapan peserta didik pada aspek kualitas materi pembelajaran untuk uji coba lapangan dan keseluruhannya dalam kriteria "Sangat Baik".

Tabel 11. Skor Penilaian Video Pembelajaran dengan Aplikasi Camtasia Mata Pelajaran Penataan dan Pemangkasan Rambut Uji Coba Lapangan Pada Aspek Kualitas Materi Pembelajaran

\begin{tabular}{|c|l|c|c|c|c|c|c|c|c|}
\hline \multirow{2}{*}{ No } & \multicolumn{1}{|c|}{ Indikator } & \multicolumn{5}{c|}{ Skor } & \multirow{2}{*}{ Jumlah } & $\begin{array}{c}\text { Rata- } \\
\text { rata }\end{array}$ & Kriteria \\
\cline { 5 - 8 } & & $\mathbf{1}$ & $\mathbf{2}$ & $\mathbf{3}$ & $\mathbf{4}$ & $\mathbf{5}$ & & \\
\hline 1 & Kesesuain materi & & & & 7 & 19 & 123 & $94,6 \%$ & Sangat Baik \\
\hline 2 & Kejelasan petunjuk belajar & & & & 6 & 20 & 124 & $95,4 \%$ & Sangat Baik \\
\hline 3 & $\begin{array}{l}\text { Kemudahan memahami } \\
\text { kalimat pada teks }\end{array}$ & & & 7 & 19 & 123 & $94,6 \%$ & Sangat Baik \\
\hline 4 & $\begin{array}{l}\text { Kemudahan memahami } \\
\text { pembelajaran }\end{array}$ & & & & 7 & 19 & 123 & $94,6 \%$ & Sangat Baik \\
\hline 5 & Ketepatan urutan penyajian & & & & 7 & 19 & 123 & $94,6 \%$ & Sangat Baik \\
\hline 6 & Kecukupan latihan & & & & 7 & 19 & 123 & $94,6 \%$ & Sangat Baik \\
\hline 7 & Kejelasan umpan balik & & & & 7 & 19 & 123 & $94,6 \%$ & Sangat Baik \\
\hline 8 & $\begin{array}{l}\text { Bantuan belajar dengan } \\
\text { program }\end{array}$ & & & & 7 & 19 & 123 & $94,6 \%$ & Sangat Baik \\
\hline & \multicolumn{1}{|c|}{ Rata-rata } & & & & & & 94,7 & $94,7 \%$ & Sangat Baik \\
\hline
\end{tabular}

Hasil evaluasi terhadap paket pembelajaran pada aspek kualitas teknis tampilan dapat dilihat pada tabel 12. Pada tabel ini menunjukkan hasil tanggapan peserta didik pada aspek kualitas teknis tampilan untuk uji coba lapangan dan keseluruhan kriteria "Sangat Baik". 
Tabel 12. Skor Penilaian Video Pembelajaran dengan Aplikasi Camtasia Mata Pelajaran Penataan dan Pemangkasan Rambut Uji Coba Lapangan Pada Aspek Kualitas Teknis/Tampilan.

\begin{tabular}{|c|c|c|c|c|c|c|c|c|c|}
\hline \multirow{2}{*}{ No } & \multirow{2}{*}{ Indikator Penilaian } & \multicolumn{5}{|c|}{ Skor } & \multirow{2}{*}{ Jumlah } & \multirow{2}{*}{$\begin{array}{l}\text { Rata- } \\
\text { Rata }\end{array}$} & \multirow{2}{*}{ Kriteria } \\
\hline & & 1 & 2 & 3 & 4 & 5 & & & \\
\hline 1 & Keindahan tampilan layar & & & & 7 & 19 & 123 & $94,6 \%$ & Sangat Baik \\
\hline 2 & Keterbacaan teks & & & & 7 & 19 & 123 & $94,6 \%$ & Sangat Baik \\
\hline 3 & Kualitas gambar dan animasi & & & & 7 & 19 & 123 & $94,6 \%$ & Sangat Baik \\
\hline 4 & Komposisi warna & & & & 5 & 21 & 125 & $96,8 \%$ & Sangat Baik \\
\hline 5 & Navigasi & & 1 & 2 & 3 & 20 & 120 & $92,3 \%$ & Sangat Baik \\
\hline 6 & Daya dukung music & & & 2 & 6 & 18 & 118 & $90,7 \%$ & Sangat Baik \\
\hline 7 & Interaksi & & 1 & 3 & 6 & 17 & 116 & $89,2 \%$ & Sangat Baik \\
\hline & Rata-rata & & & & & & 93,2 & $93,2 \%$ & Sangat Baik \\
\hline
\end{tabular}

Hasil penilaian uji coba lapangan terhadap aspek kualitas materi pembelajaran pada Video Pembelajaran dengan Aplikasi Camtasia mata pelajaran Penataan dan Pemangkasan Rambut dirangkum pada tabel 12 Dari hasil tanggapan peserta didik pada tabel 13 menyatakan bahwa aspek kualitas materi pembelajaran pada uji coba lapangan menunjukkan 23 orang siswa $(88,46 \%)$ menyatakan "Sangat Baik" dan 3 orang siswa ( $11,64 \%)$ menyatakan "Baik".

Tabel 13. Tingkat Kecendrungan Penilaian Terhadap Aspek Kualitas Materi Pembelajaran Video Pembelajaran dengan Aplikasi Camtasia Mata Pelajaran Penataan dan Pemangkasan Rambut Pada Uji Coba Lapangan

\begin{tabular}{|c|l|c|c|c|}
\hline No & \multicolumn{1}{|c|}{ Kategorisasi } & Rentang skor & Frekwensi & Persentase (\%) \\
\hline 1 & Sangat Baik & $81 \%<X<100 \%$ & 23 & 88,46 \\
\hline 2 & Baik & $61 \%<X<80 \%$ & 3 & 11,64 \\
\hline 3 & Sedang & $41 \%<X<60 \%$ & 0 & 0 \\
\hline 4 & Kurang Baik & $21 \%<X<40 \%$ & 0 & 0 \\
\hline 5 & Sangat Kurang & $0 \%<X<20 \%$ & 0 & 0 \\
\hline \multicolumn{2}{|l|}{ Jumlah } & $\mathbf{2 6}$ & $\mathbf{1 0 0}$ \\
\hline
\end{tabular}

Uji coba lapangan yang dilakukan terhadap 26 orang memberi tanggapan bahwa siswa pada umumnya menilai bahwa media pembelajaran yang dikembangkan Sangat

\section{Analisis Data Hasil Uji Coba Tahap IV Uji Coba Lapangan}

Tabel 14 menunjukkan persentase rata-rata hasil penilaian terhadap Video
Baik, tidak terdapat masalah, maka Video Pembelajaran dengan Aplikasi Camtasia telah siap untuk digunakan dalam pembelajaran dalam ketegori "sangat layak".

Pembelajaran dengan Aplikasi Camtasia mata pelajaran Penataan dan Pemangkasan Rambut pada uji coba lapangan

Tabel 14. Persentase Rata-Rata Hasil Penilaian Terhadap Video Pembelajaran dengan Aplikasi Camtasia Mata Pelajaran Penataan dan Pemangkasan Rambut Pada Uji Coba Lapangan

\begin{tabular}{|l|c|c|c|}
\hline No & Kategorisasi & Persentase rata-rata & Kriteria \\
\hline $\mathbf{1}$ & Aspek kualitas materi pembelajaran & $94,7 \%$ & Sangat Baik \\
\hline $\mathbf{2}$ & Aspek kualitas teknis/tampilan & $93,2 \%$ & Sangat Baik \\
\hline \multicolumn{2}{|c|}{ Jumlah } & $\mathbf{9 3 , 9 5 \%}$ & Sangat Baik \\
\hline
\end{tabular}

\section{Pembahasan}

Penataan dan Pemangkasan Rambut merupakan salah satu ilmu yang dalam mempelajarinya memerlukan permodelan visual yang dapat dilihat berulang-ulang sehingga diperlukan suatu media untuk memudahkan dalam memahaminya. Media pembelajaran ini berupa video pemangkasan rambut yang 
disusun/diedit dengan aplikasi Camtasia. Agar tampilan video lebih menarik dan interaktif, maka video dimuat dalam aplikasi macromedia flash yang memiliki kemampuan animasi yang interaktif, selain itu dapat mengimpor gambar dan animasi dari program lain sehingga media yang dihasilkan lebih menarik bila dipandu dengan macros. Media yang dikembangkan adalah media interaktif. Jadi akan ada penggabungan antara suara, gambar, video, tulisan animasi dan macros.

Produk pengembangan Video Pembelajaran dengan Aplikasi Camtasia pada mata pelajaran Penataan dan Pemangkasan Rambut merupakan materi pembelajaran yang telah dikembangkan dengan memperhatikan aspek pembelajaran dan media sebagai prinsip desain pesan pembelajaran. Penelitan pengembangan produk yang dilakukan ini diarahkan untuk menghasilkan suatu produk berupa Video Pembelajaran dengan Aplikasi Camtasia pada materi (a) menjelaskan pangkas rambut dan analisa pangkas rambut dasar, (b) melakukan persiapan kerja, (c) melaksanakan pangkas rambut untuk siswa SMK Negeri 3 Pematangsiantar semester I Jurusan Tata Kecantikan Rambut yang digunakan untuk meningkatkan proses pembelajaran maupun kompetensi siswa. Oleh sebab itu proses penelitian ini dilakukan dan diawali dengan, (1) studi pendahuluan, (2) kemudian mendesain media pembelajaran, (3) melakukan validasi produk dan melakukan revisi dan penyempurnaan berdasarkan analisis data validasi dari ahli materi, (4) ahli desain pembelajaran dan ahli rekayasa perangkat lunak yang dilanjutkan dengan uji coba perorangan, uji coba kelompok kecil, dan uji coba lapangan sehingga dihasilkan media pembelajaran yang layak digunakan sesuai dengan karakteristik mata pelajaran dan siswa sebagai pengguna.
Hal ini sejalan dengan pendapat Borg dan Gall (1983:772) pada buku Education Researchan Introduction yang mengemukakan bahwa penelitian pengembangan adalah penelitian yang berorientasi untuk mengembangkan dan memvalidasi produk-produk yang digunakan dalam pendidikan.

Aspek yang direvisi dan disempurnakan berdasarkan analisis data dan uji coba serta masukan dari ahli materi, ahli desain pembelajaran, ahli rekayasan perangkat lunak dan siswa selaku pengguna Video Pembelajaran dengan Aplikasi Camtasia ini, bertujuan untuk menggali beberapa aspek yang lazim dalam proses pengembangan suatu produk. Variabelvariabel media pembelajaran memiliki nilai rata-rata "Sangat Baik". Adapun variabel media pembelajaran yang dinilai meliputi kelayakan isi, penyajian, kebahasaan, pemrograman, dan kegrafikan.

Revisi dan penyempurnaan aspek berdasarkan analisis data dan uji coba serta masukan dari ahli materi, ahli desain pembelajaran, ahli media dan mahasiswa selaku pengguna media pembelajaran interaktif ini, bertujuan untuk menggali beberapa aspek yang lazim dalam proses pengembangan suatu produk. Variabelvariabel media pembelajaran memiliki nilai rata-rata sangat baik. Adapun variabel media pembelajaran yang dinilai meliputi kelayakan isi, penyajian, kebahasaan, pemrograman, dan kegrafikan.

Rangkuman persentase rata-rata hasil penilaian terhadap media pembelajaran pada mata pelajaran Penataan dan Pemangkasan Rambut oleh ahli materi, ahli desain pembelajaran, ahli media, uji coba perorangan, uji coba kelompok kecil dan uji coba lapangan dapat dilihat pada tabel 15 berikut ini:

Tabel 15. Rangkuman Persentase Rata-Rata Hasil Penilaian Terhadap Media Pembelajaran Interaktif Dengan Aplikasi Camtasia Pada Mata Pelajaran Penataan dan Pemangkasan Rambut

\begin{tabular}{|c|l|c|l|}
\hline No. & \multicolumn{1}{|c|}{ Indikator } & Persentase Rata-Rata & \multicolumn{1}{c|}{ Kriteria } \\
\hline 1 & Ahli Materi & $97,11 \%$ & Sangat Baik \\
\hline 2 & Ahli Desain Pembelajaran & $90,00 \%$ & Sangat Baik \\
\hline 3 & Ahli Media & $97,11 \%$ & Sangat Baik \\
\hline 4 & Siswa uji coba perorangan & $96,58 \%$ & Sangat Baik \\
\hline 5 & Siswa uji coba kelompok kecil & $95,80 \%$ & Sangat Baik \\
\hline 6 & Siswa uji coba lapangan & $93,95 \%$ & Sangat Baik \\
\hline \multicolumn{2}{|c|}{ Rata-Rata } & $\mathbf{9 5 , 0 9 \%}$ & Sangat Baik \\
\hline
\end{tabular}




\section{KESIMPULAN}

1. Proses penelitian dan pengembangan yang dilaksanakan telah menghasilkan media pembelajaran interaktif pada mata pelajaran Penataan dan Pemangkasan Rambut yang dikembangkan dengan Software Camtasia dan Macromedia Flash. Prosedur pengembangan media interaktif mata pelajaran Penataan dan Pemangkasan Rambut terdiri dari langkah-langkah sebagai berikut:

a) Penelitian dan mengumpulkan data yaitu termasuk analisis kebutuhan, observasi, studi literatur yang berkaitan dengan teori dan konsep pembelajaran.

b) Perencanaan pengembangan media interaktif dimulai dengan menyusun rencana penelitian, meliputi perumusan tujuan yang ingin dicapai dan mengembangkan desain.

c) Pengembangan bahan pembelajaran seperti silabus, bahan ajar dan evaluasi.

d) Melakukan uji coba dan evaluasi produk untuk mengetahui kelemahan dari produk. Melalui kegiatan evaluasi ini telah diperbaiki sejumlah kelemahan produk, baik yang menyangkut aspek desain instruksional, aspek media dan aspek materi. Evaluasi dilakukan secara bertahap yaitu mulai dari kajian ahli (expert judgment), evaluasi perorangan (one to one), evaluasi kelompok kecil (small group) dan evaluasi uji lapangan untuk melihat efektivitas media pembelajaran interaktif.

2. Hasil validasi dari ahli materi diperoleh hasil 97,11\% dikategorikan "Sangat Baik", ahli desain pembelajaran diperoleh hasil 90,00\% dikategorikan "Sangat Baik" dan ahli media pembelajaran diperoleh hasil 97,11\% dikategorikan "Sangat Baik".

3. Hasil uji coba perorangan diperoleh hasil 97,58\% dikategorikan "Sangat Baik" , uji coba kelompok kecil diperoleh hasil 95,80\% dikategorikan "Sangat Baik", dan uji coba lapangan diperoleh hasil 93,95\% dikategorikan "Sangat Baik" sehingga dapat diterima dan layak digunakan sebagai media belajar.

\section{DAFTAR PUSTAKA}

AECT. (1977). Definisi teknologi pendidikan (satuan tugas definisi \& terminologi AECT). Jakarta. Rajawali.
Arikunto, Suharsimi. (2006). Prosedur Penelitian Suatu Pendekatan Praktik. Jakarta : Rineka Cipta.

Arsyad (2002). Media Pembelajaran. Jakarta: PT Raja Garfindo Perasada.

Borg,W.R Gall. et al. (1983). Educational Research An Introduction (4thed). New York: Longman

Dick, W \& Carey, L. (2005). Systematic Desaign of Instructional (5 thed). New York : Addison-Wasley Educational Pubisher Educational Technology Publicational,Inc

George R. Knight (2007). Filsafat Pendidikan, terj Mahmud Arif, Yogyakarta: Gama Media

Isjoni. (2007). Cooperative Learning: Efektifitas Pembelajaran Kelompok. Bandung: Alfabeta.

Komaruddin, Hidayat. (2000). Active Learning. Yogyakarta. Yappendis

Kusumawardani, Hapsari. (2003). Memangkas Rambut Dasar. Malang: Tim Konsultan Fakultas Teknik.

Miarso, Yusufhadi, (2011). Menyemai Benih Teknologi Pendidikan. Jakarta: Kencana Prenada Media Group.

Moh. Surya. (1997). Psikologi Pembelajaran dan Pengajaran. Bandung. PPB - IKIP Bandung.

Rostamailis, dkk. (2008). Tata Kecantikan Rambut. Jilid 3. Jakarta : Departemen Pendidikan Nasional

Seels, Barbara B. Richey, Rita C. (1994) Teknologi Pembelajaran: definisi dan kawasannya. Penerjemah Dewi S. Prawiradilaga dkk. Jakarta: Kerjasama IPTPI LPTK UNJ

Slavin, R. E. (2010). Cooperative Learning Teori, Riset dan Praktik. Bandung: Nusa Media.

Sugiyono. (2011). Statistika Untuk Penelitian. Bandung : Alfabeta

Sukmadinata, Nana,Syaodih. (2005) Landasan Psikologi Proses Pendidikan, Bandung: PT Rosda Karya.

Waldopo. (2002). Penelitian dan pengembangan, pendekatan dalam mengembangkan produk-produk di bidang pendidikan dan pembelajaran. Sebuah Kajian Singkat pada Jurnal Teknodik. No II/VI/Teknodik. Jakarta: Pustekom. 